\title{
Sistem Informasi Penilaian Kinerja Dosen dengan MVC Framework menggunakan Simple Additive Weighting Methods
}

\author{
Liza Angriani ${ }^{\mathrm{a} 1}$, Abd. Rachman Dayat ${ }^{\mathrm{b} 2}$ \\ aProgram Studi Manajemen Informatika

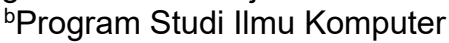 \\ STMIK Umel Mandiri \\ Jln. Raya Abepura Kotaraja Jayapura Papua 99351 \\ 1 liza.angriani2@gmail.com (Corresponding author) \\ 2abd.rachman.dayat@gmail.com
}

\begin{abstract}
Abstrak
Kinerja dosen dalam melaksanakan Tri Darma adalah suatu hal untuk mendukung pengambilan keputusan Pimpinan dalam kenaikan jabatan seorang Dosen di Perguruan Tinggi. Decisions Support System (DSS) dengan metode Simple Additive Weighting (SAW) dapat membantu dalam proses pengolahan data dan memperbaiki kekurangan seperti kesalahan dalam perhitungan dan dalam penyajian laporan selama ini. Tujuan dari penelitian ini adalah untuk memanfaatkan metode SAW dalam penilaian kinerja dosen. Metodologi yang digunakan dalam melakukan penelitian adalah diawali dengan pengumpulan data dan dilanjutkan dengan tahap mengembangkan menjadi suatu sistem informasi. Hasil penelitian ini adalah menghasilkan Sistem Informasi Penilaian Kinerja Dosen memanfaatkan teknologi MVC Framework dengan metode SAW sebagai sarana penunjang pengambilan keputusan di AMIK Umel Mandiri.
\end{abstract}

Kata Kunci: Decisions Support System, Kinerja Dosen, Simple Additive Weighting Methods

\begin{abstract}
The performance of lecturers in implementing the "Tri Darma Perguruan Tinggi" is something to support the leadership's decision making in the promotion of a lecturer in a university. The Decisions Support System (DSS) with the Simple Additive Weighting (SAW) method can assist in the data processing and fix deficiencies such as errors in calculations and in the presentation of reports so far. The purpose of this study was to utilize the SAW method in assessing lecturer performance. The methodology used in conducting research begins with data collection and continues with the stage of developing into an information system. The results of this study are to produce a Lecturer Performance Assessment Information System utilizing MVC Framework technology with the SAW method as a means of supporting decision making at AMIK Umel Mandiri.
\end{abstract}

Keywords: Decisions Support System, Lecturer Performance, Simple Additive Weighting Methods

\section{Pendahuluan}

Dosen adalah seseorang yang secara langsung berhadapan dengan mahasiswa dan merupakan salah satu indikator dari keberhasilan suatu program studi pada perguruan tinggi [1]. Penilaian kinerja dosen dalam suatu perguruan tinggi merupakan suatu kegiatan untuk mengevaluasi kinerja dari setiap dosen yang ada dalam perguruan tinggi [2]. Pelaksanaan evaluasi kinerja dosen merupakan suatu aktifitas yang secara rutin dilakukan pada perguruan tinggi untuk meningkatkan kualitas dosen secara berkelanjutan [3].

Rutinitas monitoring dan evaluasi kinerja dosen dalam perkembangannya mengalami hambatan dengan semakin meningkatnya jumlah mahasiswa dan terbatasnya jumlah petugas. Selain 
pengolahan data hanya diolah menggunakan perangkat lunak Microsoft Excel, sampai saat ini belum ada perangkat lunak yang secara khusus untuk mengolah data sebagai alat untuk melakukan monitoring dan evaluasi kinerja dosen. Hasil monitoring dan evaluasi kinerja dosen selama ini berupa rekapitulasi yang bersumber dari data-data kuisioner mahasiswa terkait proses belajar mengajar dan belum mencakup kegiatan dosen di bidang penelitian dan pengabdian pada masyarakat. Permasalahan ini berdampak pada:

1. Membutuhkan waktu yang lama dalam melakukan proses pengolahan data kuisioner mahasiswa oleh bagian akademik.

2. Hasil evaluasi kinerja dosen yang masih kurang lengkap karena belum mencakup bidang penelitian dan pengabdian pada masyarakat.

3. Hasil evaluasi kinerja dosen yang belum sesuai dengan pedoman evaluasi kinerja dosen yang sudah ditetapkan institusi.

4. Sulitnya institusi dalam menentukan kebijakan-kebijakan terkait peningkatan kualitas dosen seperti: studi lanjut, pelatihan, dan penghargaan karena tidak adanya data kinerja dosen secara historis.

5. Menjadi hambatan bagi institusi dalam peningkatan status akreditasi karena salah satu penilaian akreditasi adalah riwayat pelaksanaan kegiatan tridharma perguruan tinggi oleh dosen dalam kurun waktu tertentu.

Perkembangan teknologi dan informasi sekarang ini sudah sangat pesat. Teknologi komputer dapat dimanfaatkan untuk pemenuhan kebutuhan akan informasi, di antaranya adalah Decisions Support System (DSS) atau sistem pendukung pengambilan keputusan [4]. Akademi Manajemen Informatika dan Komputer (AMIK Umel Mandiri) Program Studi Manajemen Informatika setiap akhir semester mengadakan evaluasi kinerja dosen yang dinilai oleh mahasiswa dengan memberikan penilaian pada lembar atau mengisi kuisioner. Pengolahan data hasil dari kuisioner sudah terkomputerisasi namun belum ada aplikasi khusus yang mengolah data tersebut. DSS dengan metode Simple Additive Weighting (SAW) dapat membantu dalam proses pengolahan data dan memperbaiki kekurangan seperti kesalahan dalam perhitungan dan dalam penyajian laporan selama ini.

Berdasarkan latar belakang tersebut, dapat dirumuskan permasalahan yaitu bagaimana Pemanfaatan metode Simple Additive Weighting (SAW) untuk penilaian kinerja dosen (Studi Kasus AMIK Umel Mandiri Jayapura).

\section{Reseach Methods}

Metodologi yang digunakan dalam melakukan penelitian adalah diawali dengan pengumpulan data dilanjutkan dengan tahap develop sistem informasi [5]. Diagram Alir Penelitian dapat dilihat pada Gambar 1.

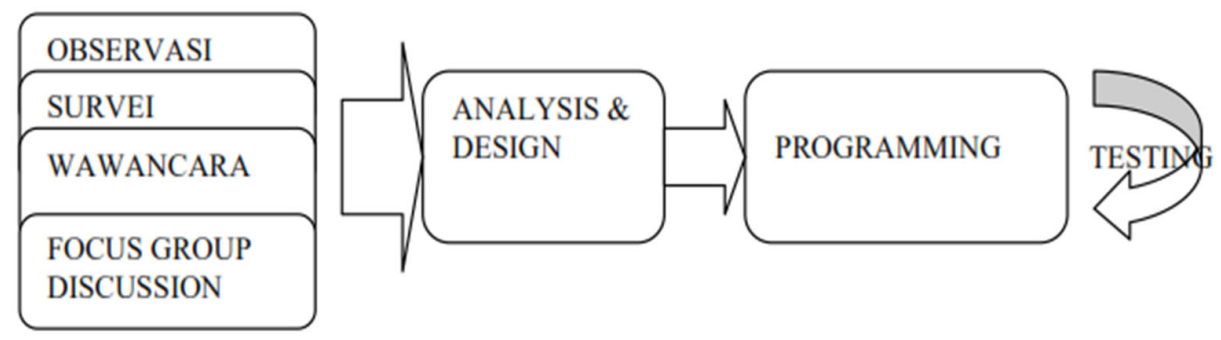

PENGUMPULAN DATA

\section{DEVELOP SYSTEM}

Gambar 1. Diagram Alir Penelitian

Cara perhitungan dari Metode SAW yaitu dengan menentukan nilai bobot dari setiap kriteria, kemudian dilanjutkan dengan proses perangkingan yang akan menyeleksi alternatif terbaik dari sejumlah alternatif.

Pada metode ini terdapat nilai bobot dari kriteria yang digunakan sebagai acuan dalam perhitungan perangkingannya. Dan dalam sistem yang dirancang ini sudah ditentukan kriteria beserta nilai bobotnya, diantaranya sebagai berikut: 
1. $\mathrm{C} 1=$ Dosen selalu mempunyai materi

2. $\mathrm{C} 2$ = Dosen mengalokasikan waktu untuk diskusi

3. C3 = Bahan ajar untuk melengkapi materi

4. $\mathrm{C} 4=$ Memberikan nilai ujian yang objektif

5. $\mathrm{C} 5=$ Dosen selalu datang tepat waktu

6. $\mathrm{C} 6=$ Memberikan silabus perkuliahan

7. $\mathrm{C} 7=$ Dosen menguasai materi

Dari masing-masing kriteria tersebut ditentukan nilai bobotnya, nilai ini digunakan untuk menghitung perangkingan dari semua alternatif. Nilai tersebut diantaranya sebagai berikut:
1. $C 1=20 \%$
5. $\mathrm{C} 5=10 \%$
2. $\mathrm{C} 2=10 \%$
6. $\mathrm{C} 6=20 \%$
3. $\mathrm{C} 3=10 \%$
7. $C 7=10 \%$
4. $C 4=20 \%$

Tabel 1. Contoh Data Alternatif dan Nilai Kinerja Dosen

\begin{tabular}{|c|c|c|c|c|c|c|c|}
\hline \multirow{2}{*}{$\begin{array}{c}\text { Alternatif } \\
(\mathbf{A i})\end{array}$} & \multicolumn{7}{|c|}{ Tabel Alternatif dan Nilai Kriteria Dosen } \\
\cline { 2 - 8 } & C1 & C2 & C3 & C4 & C5 & C6 & C7 \\
\hline A1 & 3 & 4 & 4 & 3 & 3 & 4 & 5 \\
\hline A2 & 4 & 3 & 5 & 3 & 2 & 4 & 4 \\
\hline A3 & 3 & 4 & 4 & 2 & 2 & 3 & 3 \\
\hline A4 & 4 & 5 & 4 & 3 & 2 & 3 & 3 \\
\hline A5 & 5 & 4 & 3 & 2 & 2 & 3 & 4 \\
\hline A6 & 4 & 3 & 2 & 3 & 4 & 4 & 5 \\
\hline A7 & 4 & 3 & 4 & 3 & 5 & 4 & 4 \\
\hline
\end{tabular}

Kemudian memasukkan semua nilai data pencocokan alternatif dan kriteria ke dalam matrik berikut:

$$
\text { Matriks X }=\left(\begin{array}{ccccccc}
3 & 4 & 4 & 3 & 3 & 4 & 5 \\
4 & 3 & 5 & 3 & 2 & 4 & 4 \\
3 & 4 & 4 & 2 & 2 & 3 & 3 \\
4 & 5 & 4 & 3 & 2 & 3 & 3 \\
5 & 4 & 3 & 2 & 2 & 3 & 4 \\
4 & 3 & 2 & 3 & 4 & 4 & 5 \\
4 & 3 & 4 & 3 & 5 & 4 & 4
\end{array}\right)
$$

Selanjutnya menghitung nilai pada matrik dengan menggunakan rumus benefit atau cost, hasil perhitungan ini dimasukan kedalam matrik Normalisasi (R) dengan menggunakan rumus sebagai berikut :

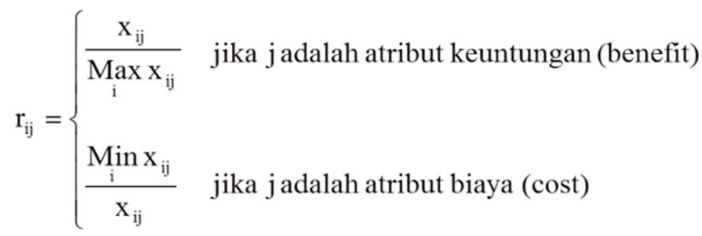

Berdasarkan matrik tersebut, maka dapat dihasilkan nilai kriteria sebagai berikut:

a. C1: Dosen selalu mempunyai materi (atribut benefit), makin besar nilainya maka dianggap semakin baik, sehingga: 


$$
\begin{aligned}
& \mathrm{R} 11=\frac{3}{\operatorname{Max}(3,4,3,4,5,5,4)}=\frac{3}{5}=0,6 \\
& \mathrm{R} 12=\frac{4}{\operatorname{Max}(3,4,3,4,4,5,4,4)}=\frac{4}{5}=0,8 \\
& \mathrm{R} 13=\frac{3}{\operatorname{Max}(3,4,3,4,4,5,4,4)}=\frac{3}{5}=0,6 \\
& \mathrm{R} 14=\frac{4}{\operatorname{Max}(3,4,3,4,4,5,4,4)}=\frac{4}{5}=0,8 \\
& \mathrm{R} 15=\frac{5}{\operatorname{Max}(3,4,3,4,5,4,4)}=\frac{5}{5}=1 \\
& \mathrm{R} 16=\frac{4}{\operatorname{Max}(3,4,3,4,5,5,4,4)}=\frac{4}{5}=0,8 \\
& \mathrm{R} 17=\frac{4}{\operatorname{Max}(3,4,3,4,5,4,4)}=\frac{4}{5}=0,8
\end{aligned}
$$

b. C2: Dosen mengalokasikan waktu untuk diskusi (atribut benefit), makin besar nilainya maka dianggap semakin baik, sehingga:

$$
\begin{aligned}
& \mathrm{R} 21=\frac{4}{\operatorname{Max}(4,3,4,5,4,3,3)}=\frac{4}{5}=0,8 \\
& \mathrm{R} 22=\frac{3}{\operatorname{Max}(4,3,4,5,4,3,3)}=\frac{3}{5}=0,6 \\
& \mathrm{R} 23=\frac{4}{\operatorname{Max}(4,3,4,5,4,3,3)}=\frac{4}{5}=0,8 \\
& \mathrm{R} 24=\frac{5}{\operatorname{Max}(4,3,4,5,4,3,3)}=\frac{5}{5}=1 \\
& \mathrm{R} 25=\frac{4}{\operatorname{Max}(4,3,4,5,4,3,3)}=\frac{4}{5}=0,8 \\
& \mathrm{R} 26=\frac{3}{\operatorname{Max}(4,3,4,5,4,3,3)}=\frac{3}{5}=0,6 \\
& \mathrm{R} 27=\frac{3}{\operatorname{Max}(4,3,4,5,4,3,3)}=\frac{3}{5}=0,6
\end{aligned}
$$

c. C3: Bahan ajar untuk melengkapi materi (atribut benefit), makin besar nilainya maka dianggap semakin baik, sehingga:

$$
\begin{aligned}
& \mathrm{R} 31=\frac{4}{\operatorname{Max}(4,5,4,4,3,2,4)}=\frac{4}{5}=0,8 \\
& \mathrm{R} 32=\frac{5}{\operatorname{Max}(4,5,4,4,3,2,4)}=\frac{5}{5}=1 \\
& \mathrm{R} 33=\frac{4}{\operatorname{Max}(4,5,4,4,4,3,2,4)}=\frac{4}{5}=0,8 \\
& \mathrm{R} 34=\frac{4}{\operatorname{Max}(4,5,4,4,3,2,4)}=\frac{4}{5}=0,8 \\
& \mathrm{R} 35=\frac{3}{\operatorname{Max}(4,5,4,4,3,2,4)}=\frac{3}{5}=0,6 \\
& \mathrm{R} 36=\frac{2}{\operatorname{Max}(4,5,4,4,4,3,2,4)}=\frac{2}{5}=0,4 \\
& \mathrm{R} 37=\frac{4}{\operatorname{Max}(4,5,4,4,3,3,2,4)}=\frac{4}{5}=0,8
\end{aligned}
$$

d. C4: Dosen selalu mempunyai materi (atribut benefit), makin besar nilainya maka dianggap semakin baik, sehingga:

$$
\begin{aligned}
& \mathrm{R} 41=\frac{3}{\operatorname{Max}(3,3,2,3,2,2,3)}=\frac{3}{3}=1 \\
& \mathrm{R} 42=\frac{3}{\operatorname{Max}(3,3,2,3,2,3,3)}=\frac{3}{3}=1 \\
& \mathrm{R} 43=\frac{2}{\operatorname{Max}(3,3,2,3,2,2,3,3)}=\frac{2}{3}=0,66 \\
& \mathrm{R} 44=\frac{3}{\operatorname{Max}(3,3,2,3,2,3,3)}=\frac{3}{3}=1 \\
& \mathrm{R} 45=\frac{2}{\operatorname{Max}(3,3,2,3,2,2,3,3)}=\frac{2}{3}=0,66 \\
& \mathrm{R} 46=\frac{3}{\operatorname{Max}(3,3,2,2,3,2,3,3)}=\frac{3}{3}=1 \\
& \mathrm{R} 47=\frac{3}{\operatorname{Max}(3,3,2,3,2,3,3)}=\frac{3}{3}=1
\end{aligned}
$$

e. C5: Dosen memberikan nilai ujian (atribut benefit), makin besar nilainya maka dianggap semakin baik, sehingga: 


$$
\begin{aligned}
& \mathrm{R} 51=\frac{3}{\operatorname{Max}(3,2,2,2,2,4,5)}=\frac{3}{5}=0,6 \\
& \mathrm{R} 52=\frac{2}{\operatorname{Max}(3,2,2,2,2,2,4,5)}=\frac{2}{5}=0,4 \\
& \mathrm{R} 53=\frac{2}{\operatorname{Max}(3,2,2,2,2,4,5)}=\frac{2}{5}=0,4 \\
& \mathrm{R} 54=\frac{2}{\operatorname{Max}(3,2,2,2,2,4,5)}=\frac{2}{5}=0,4 \\
& \mathrm{R} 55=\frac{2}{\operatorname{Max}(3,2,2,2,2,2,4,5)}=\frac{2}{5}=0,4 \\
& \mathrm{R} 56=\frac{4}{\operatorname{Max}(3,2,2,2,2,4,5)}=\frac{4}{5}=0,8 \\
& \mathrm{R} 57=\frac{5}{\operatorname{Max}(3,2,2,2,2,4,5)}=\frac{5}{5}=1
\end{aligned}
$$

f. C6: Dosen memberikan silabus perkuliahan (atribut benefit), makin besar nilainya maka dianggap semakin baik, sehingga:

$$
\begin{aligned}
& \mathrm{R} 61=\frac{4}{\operatorname{Max}(4,4,3,3,3,4,4)}=\frac{4}{4}=1 \\
& \mathrm{R} 62=\frac{4}{\operatorname{Max}(4,4,3,3,3,3,4,4)}=\frac{4}{4}=1 \\
& \mathrm{R} 63=\frac{3}{\operatorname{Max}(4,4,3,3,3,3,4,4)}=\frac{3}{4}=0,75 \\
& \mathrm{R} 64=\frac{3}{\operatorname{Max}(4,4,3,3,3,4,4)}=\frac{3}{4}=0,75 \\
& \mathrm{R} 65=\frac{3}{\operatorname{Max}(4,4,3,3,3,3,4,4)}=\frac{3}{4}=0,75 \\
& \mathrm{R} 66=\frac{4}{\operatorname{Max}(4,4,3,3,3,3,4,4)}=\frac{4}{4}=1 \\
& \mathrm{R} 67=\frac{4}{\operatorname{Max}(4,4,3,3,3,3,4,4)}=\frac{4}{4}=1
\end{aligned}
$$

g. C7: Dosen menguasai materi (atribut benefit), makin besar nilainya maka dianggap semakin baik, sehingga:

$$
\begin{aligned}
& \mathrm{R} 71=\frac{5}{\operatorname{Max}(5,4,3,3,4,5,5,4)}=\frac{5}{5}=1 \\
& \mathrm{R} 72=\frac{4}{\operatorname{Max}(5,4,3,3,3,4,5,4)}=\frac{4}{5}=0,8 \\
& \mathrm{R} 73=\frac{3}{\operatorname{Max}(5,4,3,3,4,5,5)}=\frac{3}{5}=0,6 \\
& \mathrm{R} 74=\frac{3}{\operatorname{Max}(5,4,3,3,4,5,4)}=\frac{3}{5}=0,6 \\
& \mathrm{R} 75=\frac{4}{\operatorname{Max}(5,4,3,3,3,4,5,4)}=\frac{4}{5}=0,8 \\
& \mathrm{R} 76=\frac{5}{\operatorname{Max}(5,4,4,3,3,4,5,4)}=\frac{5}{5}=1 \\
& \mathrm{R} 77=\frac{4}{\operatorname{Max}(5,4,3,3,3,4,5,4)}=\frac{4}{5}=0,8
\end{aligned}
$$

Sehingga hasil normalisasi perhitungan Matriks $\mathrm{R}$ adalah:

$$
\text { Matriks R }=\left(\begin{array}{lllllll}
0,6 & 0,8 & 0,8 & 1 & 0,6 & 1 & 1 \\
0,8 & 0,6 & 1 & 1 & 0,4 & 1 & 0,8 \\
0,6 & 0,8 & 0,8 & 0,66 & 0,4 & 0,75 & 0,6 \\
0,8 & 1 & 0,8 & 1 & 0,4 & 0,75 & 0,6 \\
1 & 0,8 & 0,6 & 0,66 & 0,4 & 0,75 & 0,8 \\
0,8 & 0,6 & 0,4 & 1 & 0,8 & 1 & 1 \\
0,8 & 0,6 & 0,8 & 1 & 1 & 1 & 0,8
\end{array}\right)
$$

Selanjutnya, menentukan bobot preferensi atau tingkat kepentingan (W) atas setiap kriteria, dan menghitung nilai rangking $(\mathrm{V})$ dari setiap alternatif dengan cara mengkalikan setiap nilai alternatif pada matrik normalisasi $(\mathrm{R})$ dengan bobot preferensi $(\mathrm{W})$, berikut rumusnya:

$$
\mathrm{V}_{\mathrm{i}}=\sum_{\mathrm{j}=1}^{\mathrm{n}} \mathrm{w}_{\mathrm{j}} \mathrm{r}_{\mathrm{ij}}
$$


Sehingga didapatkan hasil perhitungannya sbb:

$$
\begin{aligned}
& \mathrm{V} 1=(0.20)(0.6)+(0.10)(0.8)+(0.10)(0.8)+(0.20)(1)+(0.10)(0.6)+(0.20)(1)+(0.10)(1) \\
& =0.12+0.08+0.08+0.2+0.06+0.2+0.1 \\
& =0.84 \\
& \mathrm{~V} 2=(0.20)(0.8)+(0.10)(0.6)+(0.10)(1)+(0.20)(1)+(0.10)(0.4)+(0.20)(1)+(0.10)(0.8) \\
& =0.16+0.06+0.1+0.2+0.04+0.2+0.08 \\
& =0.84 \\
& \text { V3 }=(0.20)(0.6)+(0.10)(0.8)+(0.10)(0.8)+(0.20)(0.66)+(0.10)(0.4)+(0.20)(0.75)+(0.10)(0.6) \\
& =0.12+0.08+0.08+0.132+0.04+0.15+0.06 \\
& =0.662 \\
& \mathrm{~V} 4=(0.20)(0.8)+(0.10)(1)+(0.10)(0.8)+(0.20)(1)+(0.10)(0.4)+(0.20)(0.75)+(0.10)(0.6) \\
& =0.16+0.1+0.08+0.2+0.04+0.15+0.06 \\
& =0.79 \\
& \mathrm{~V} 5=(0.20)(1)+(0.10)(0.8)+(0.10)(0.6)+(0.20)(0.667)+(0.10)(0.4)+(0.20)(0.75)+(0.10)(0.8) \\
& =0.2+0.08+0.06+0.1334+0.04+0.15+0.08 \\
& =0.7434 \\
& \text { V6 }=(0.20)(0.8)+(0.10)(0.6)+(0.10)(0.4)+(0.20)(1)+(0.10)(0.8)+(0.20)(1)+(0.10)(1) \\
& =0.16+0.06+0.04+0.2+0.08+0.2+0.1 \\
& =0.84 \\
& \text { V7 }=(0.20)(0.8)+(0.10)(0.6)+(0.10)(0.8)+(0.20)(1)+(0.10)(1)+(0.20)(1)+(0.10)(0.8) \\
& =0.16+0.06+0.08+0.2+0.1+0.2+0.08 \\
& =0.88
\end{aligned}
$$

Tahap terakhir, menjumlahkan setiap nilai ranking (V) untuk setiap alternatif, sehingga diperoleh nilai perangkingan $\mathrm{V}$ untuk hasil dari perhitungan metode SAW, dengan hasil sebagaimana terlihat pada Tabel 2.

Tabel 2. Hasil Perangkingan Dosen

\begin{tabular}{|c|c|c|}
\hline No & Variabel / Nama Dosen & Nilai \\
\hline 1 & Dosen 7 & 0.88 \\
\hline 2 & Dosen 2 & 0.84 \\
\hline 3 & Dosen 1 & 0.84 \\
\hline 4 & Dosen 6 & 0.84 \\
\hline 5 & Dosen 4 & 0.79 \\
\hline 6 & Dosen 3 & 0.662 \\
\hline 7 & Dosen 5 & 0.7434 \\
\hline
\end{tabular}

\section{Hasil dan Pembahasan}

\subsection{Analisis Perancangan Sistem}

Berikut merupakan proses bisnis sistem penilaian kinerja dosen yang diusulkan.

1. Direktur AMIK Umel Mandiri menugaskan penilaian kinerja dosen kepada Ketua UPM.

2. Setelah menerima tugas penilaian kinerja dosen, Ketua UPM sebagai admin, memasukan data kriteria penilaian dan bobot penilaian untuk setiap dosen yang akan dinilai kinerjanya ke 
Menu Penilaian Kinerja Dosen pada Sistem Informasi Penilaian Kinerja Dosen. Dan menugaskan Staf Administrasi Akademik dan Kemahasiswaan (BAAK) untuk membuat pemberitahuan bahwa mahasiswa diharuskan mengisi kuesioner online penilaian kinerja dosen di sistem.

3. Selanjutnya pada saat waktu pengisian kuesioner yaitu pada saat mahasiswa akan melakukan perwalian semester selanjutnya, BAAK memberitahukan mahasiswa untuk mengisi kuesioner penilaian kinerja dosen yang bersangkutan di Sistem Informasi Penilaian Kinerja Dosen.

4. Kemudian Mahasiswa yang memiliki hak akses sebagai mahasiswa, mengisi kuesioner dengan memilih jawaban tanggapan atas pernyataan-pernyataan kriteria penilaian kinerja dosen yang bersangkutan pada Sistem Informasi Penilaian Kinerja Dosen.

5. Setelah semua mahasiswa telah mengisi kuesioner online tersebut, Ketua UPM memberitahukan kepada Direktur AMIK Umel Mandiri yang memiliki hak akses sebagai pimpinan melihat hasil penilaian pada menu Penilaian. Juga dapat mencetak hasil penilaian kinerja dosen tersebut.

6. Dalam hal penilaian kinerja dosen, sistem melakukan perhitungan dengan metode Simple Additive Weighting (SAW), dimana secara komputerisasi akan langsung melakukan penilaian sesuai jumlah data kuesioner yang ada pada basis data dengan perhitungan metode Simple Aditive Weighting (SAW).

\subsection{Implementasi Sistem}

Setelah melakukan perancangan dan analisis sistem, solusi berikutnya berupa aplikasi penilaian kinerja pegawai berbasis web menggunakan metode Simple Additive Weighting (SAW). Sistem Informasi Penilaian Kinerja Dosen ini memiliki 2 (dua) level pengguna, yaitu Mahasiswa dan Admin, di mana Mahasiswa adalah end-user yang akan menilai Dosen yang mengampu mata kuliah semester berjalan dan Admin adalah super-user yang mengatur Sistem Informasi secara keseluruhan. Berikut adalah tahapan kerja sistem secara keseluruhan.

1. Tampilan Login Mahasiswa

Halaman ini merupakan halaman yang awal yang ditampilkan kepada user. Setiap user didaftarkan oleh admin, sehingga user menerima username dan password yang diberikan oleh admin. Untuk dapat masuk ke halaman utama dashboard, user yang terdaftar harus melakukan proses login melalui halaman ini. Pengguna hanya perlu memasukkan username dan password. Kemudian sistem akan melakukan verifikasi dari data pengguna yang telah dimasukkan. Tampilan menu login mahasiswa dapat dilihat pada Gambar 2.

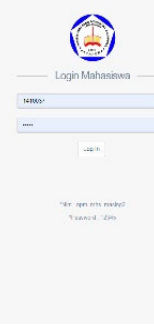

Gambar 2. Tampilan Login Mahasiswa

2. Tampilan Dashboard Mahasiswa

Halaman ini merupakan halaman utama dari user mahasiswa, dimana akan tampil seluruh mata kuliah yang diprogramkan pada semester berjalannya, yang mana mahasiswa bisa memberikan penilaian kepada dosen berdasarkan mata kuliahnya. Tampilan menu dashboard mahasiswa dapat dilihat pada Gambar 3. 


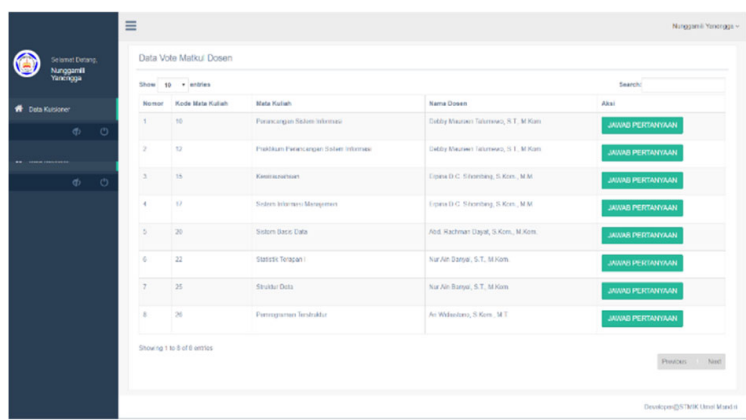

Gambar 3. Tampilan Dashboard Mahasiswa

3. Tampilan Kuesioner Dosen

Halaman ini adalah lanjutan dari menu sebelumnya, dimana menampilkan kuesioner penilaian dosen berdasarkan mata kuliah. Ada 35 pertanyaan yang diberikan, nilai 1 adalah paling buruk dan 5 adalah nilai paling baik. Tampilan menu kuesioner dosen dapat dilihat pada Gambar 4.

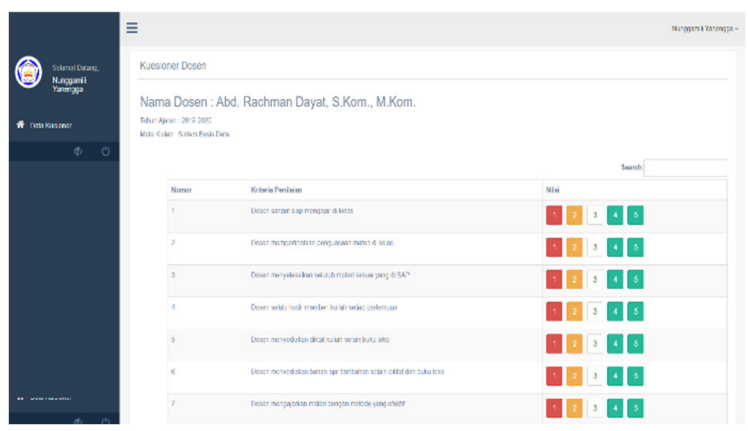

Gambar 4. Tampilan Kuesioner Dosen

4. Tampilan Menu Login Administrator

Halaman ini digunakan oleh administrator, dalam hal ini adalah Kepala Unit Penjaminan Mutu AMIK Umel Mandiri untuk melihat hasil isian kuesioner yang telah dinilai oleh setiap mahasiswa. Tampilan menu login administrator dapat dilihat pada Gambar 5.

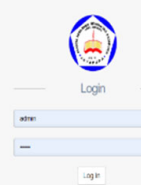

Gambar 5. Tampilan Menu Login Administrator

5. Tampilan Menu Data Mata Kuliah

Menu Data Mata Kuliah ini digunakan oleh admin untuk menambahkan mata kuliah berdasarkan semester yang berjalan beserta nama dosen yang mengampu. Tampilan menu data mata kuliah dapat dilihat pada Gambar 6. 


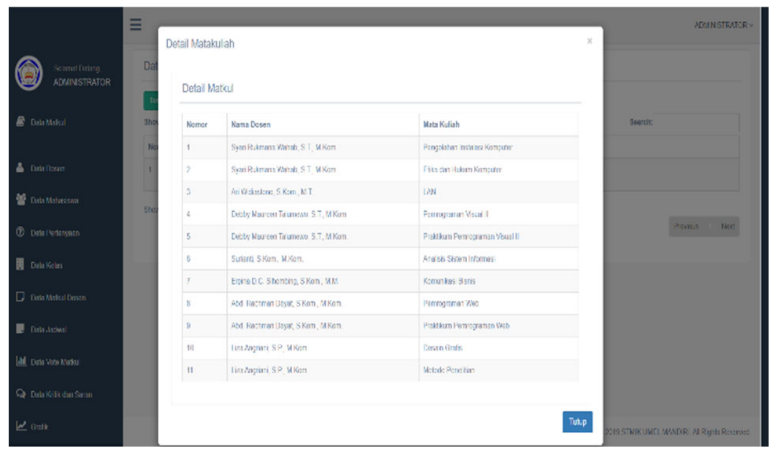

Gambar 6. Tampilan Menu Data Mata Kuliah

6. Tampilan Menu Data Kelas

Menu Data Kelas adalah menu untuk mengalokasikan mahasiswa berdasarkan semester dan kelas yang diambil, yang nantinya akan berelasi dengan mata kuliah yang diprogramkan. Tampilan menu data kelas dapat dilihat pada Gambar 7.

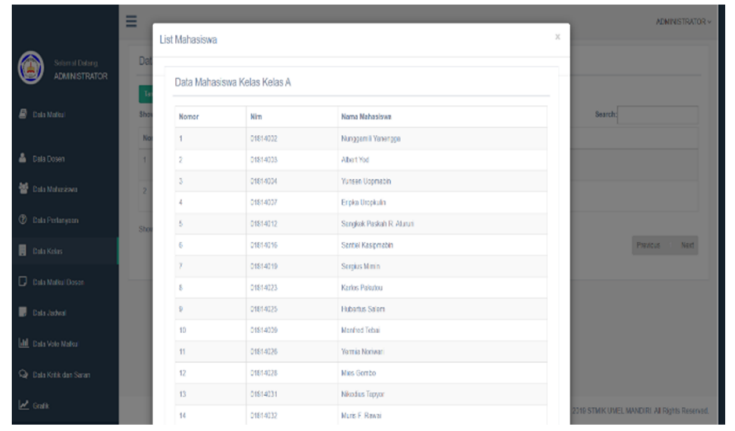

Gambar 7. Tampilan Menu Data Kelas

7. Tampilan Menu Data Pertanyaan

Menu ini adalah menu untuk menambahkan data pertanyaan pada kuesioner yang akan diberikan kepada mahasiswa. Setiap pertanyaan/kelompok pertanyaan memiliki bobot yang nantinya akan dihitung oleh sistem menggunakan metode Simple Additive Weighting (SAW). Tampilan menu data pertanyaan dapat dilihat pada Gambar 8.

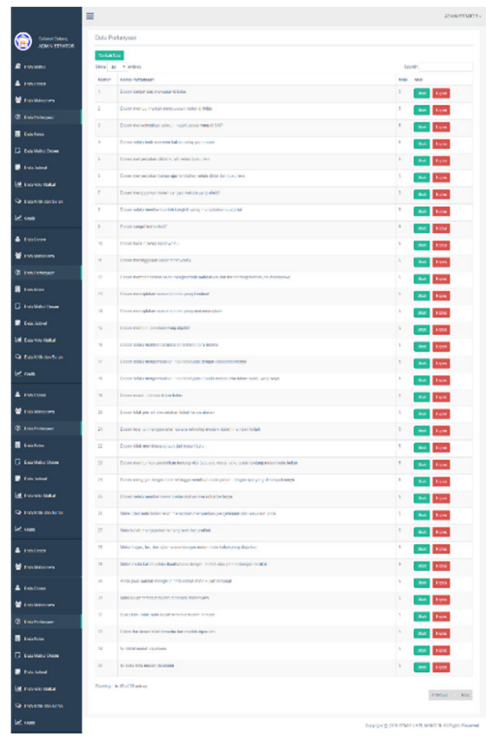

Gambar 8. Tampilan Menu Data Pertanyaan 
8. Tampilan Menu Hasil Kuesioner

Menu Data Vote Mata Kuliah (Hasil Kuesioner) adalah menu untuk melihat hasil penilaian Dosen berdasarkan mata kuliah yang diampu pada tahun ajaran yang berjalan. Tampilan menu hasil kuesioner dapat dilihat pada Gambar 9.

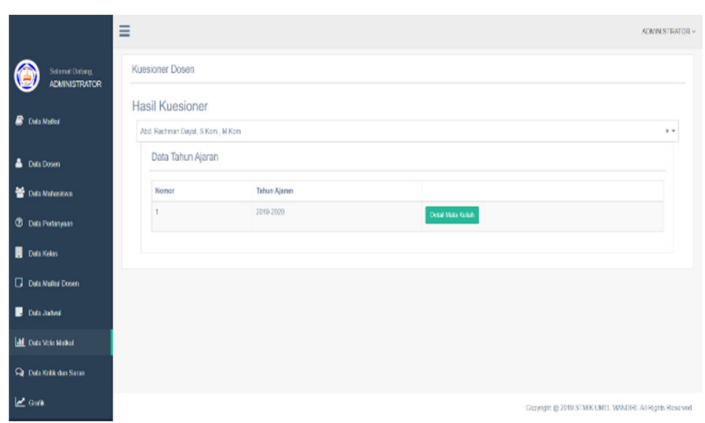

Gambar 9. Tampilan Menu Hasil Kuesioner

Hasil kuesioner dari mata kuliah yang diajarkan oleh dosen tersebut akan ditampilkan sesuai dengan penilaian yang diberikan oleh mahasiswa. Semakin baik cara dosen mengajar akan semakin baik nilai yang dihasilkan. Nilai rata-rata yang dikeluarkan oleh SAW adalah nilai 1 untuk paling buruk dan nilai 5 merupakan nilai yang paling baik. Tampilan menu detail hasil kuesioner dapat dilihat pada Gambar 10.

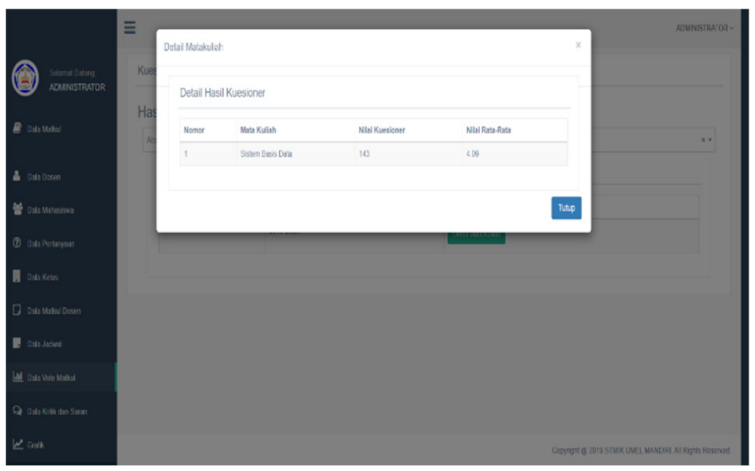

\section{Kesimpulan}

Gambar 10. Tampilan Detail Hasil Kuesioner

Berdasarkan hasil pengujian yang telah dilakukan, maka dapat diambil kesimpulan diantaranya sebagai berikut:

1. Penelitian ini berhasil membangun sebuah sistem informasi Penilaian Kinerja Dosen memanfaatkan Metode Simple Additive Weighting (SAW) sebagai metode untuk menghitung bobot dari beberapa kriteria penilaian dosen di AMIK Umel Mandiri.

2. Dengan memanfaatkan Sistem Informasi Penilaian Kinerja Dosen ini, AMIK Umel Mandiri tidak perlu lagi menyebar kuesioner fisik kepada mahasiswa di akhir semester, cukup mengakses halaman web agar mahasiswa dapat melakukan penilaian terhadap dosen mata kuliahnya.

\section{Ucapan Terima Kasih}

Terima kasih kepada Direktorat Riset dan Pengabdian kepada Masyarakat Direktorat Jenderal Penguatan Riset dan Pengembangan Kementerian Riset, Teknologi, dan Pendidikan Tinggi Republik Indonesia yang telah memberikan dana hibah Penelitian Dosen Pemula Tahun Anggaran 2019. 


\section{Referensi}

[1] Erwin Panggabean. 2016. Sistem Pendukung Keputusan Evaluasi Kinerja Dosen menggunakan Metode Fuzzy Simple Additive Weighting (FSAW). Jurnal Mantik. Volume 19 (1).

[2] Yoga Handoko Agustin, dan Hendra Kurniawan. 2015. Sistem Pendukung Keputusan Penilaian Kinerja Dosen menggunakan Metode Weighted Product (Studi Kasus: STMIK Pontianak). SemnasIF. 22 Agustus 2015. Medan: Universitas Potensi Utama. ISSN: 20889747. Hal. $177-182$.

[3] Hamzah, Suyoto, dan Paulus Mudjihartono. 2010. Sistem Pendukung Keputusan Penilaian Kinerja Dosen dengan Metode Balanced Scorecard (Studi Kasus Universitas Respati Yogyakarta). SemnasIF. 22 Mei 2010. Yogyakarta: UPN "Veteran". ISSN: 1979-2328.

[4] A. Widiastono, NA. Banyal, dan L. Angriani. 2016. Sistem Informasi Troubleshooting pada Personal Computer (PC). Ilkom Jurnal Ilmiah. Volume 8 (2): 103 - 110.

[5] AR. Dayat dan L. Angriani. 2017. Pemanfaatan Model-View-Controller (MVC) dalam Rancang Bangun Sistem Informasi RAKORNAS APTIKOM 2017. SEMNASTIKOM. 03 